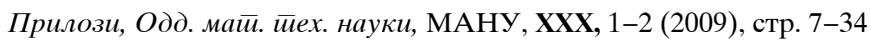
Contributions, Sec. Math. Tech. Sci., MANU, XXX, 1-2 (2009), pp. 7-34

ISSN $0351-3246$

UDC: $549.08: 543.42(497.7)$

Review

\title{
MINERALS FROM MACEDONIA. X-RAY POWDER DIFFRACTION vs. VIBRATIONAL SPECTROSCOPY IN MINERAL IDENTIFICATION
}

\section{Gligor Jovanovski, Petre Makreski, Branko Kaitner, Bojan Šoptrajanov}

\begin{abstract}
$\mathrm{A} \mathrm{b} \mathrm{s} \mathrm{t} \mathrm{r} \mathrm{a} \mathrm{c} \mathrm{t:} \mathrm{Some} \mathrm{of} \mathrm{the} \mathrm{advantages} \mathrm{and} \mathrm{imperfections} \mathrm{in} \mathrm{the}$ cases when the X-ray powder diffraction (XRPD), Fourier transform infrared (FTIR) or Raman vibrational spectroscopy are used as a separated techniques in the process of the mineral detection, identification, discrimination and characterization are comparatively presented. The studied mineral samples: rutile, $\mathrm{TiO}_{2}$; hematite, $\mathrm{Fe}_{2} \mathrm{O}_{3}$; almandine, $\mathrm{Fe}_{3} \mathrm{Al}_{2}\left(\mathrm{SiO}_{4}\right)_{3}$; spessartine, $\mathrm{Mn}_{3} \mathrm{Al}_{2}\left(\mathrm{SiO}_{4}\right)_{3}$; limonite, $\mathrm{FeO}(\mathrm{OH})$; goethite, $\alpha-\mathrm{FeO}(\mathrm{OH})$; ferrojohannsenite, $\mathrm{Ca}(\mathrm{Fe}, \mathrm{Mn}) \mathrm{Si}_{2} \mathrm{O}_{6}$; olivine, $(\mathrm{Mg}, \mathrm{Fe})_{2} \mathrm{SiO}_{4}$; forsterite, $\mathrm{Mg}_{2} \mathrm{SiO}_{4}$; fayalite, $\mathrm{Fe}_{2} \mathrm{SiO}_{4}$; beryl, $\mathrm{Be}_{3} \mathrm{Al}_{2} \mathrm{Si}_{6} \mathrm{O}_{18}$; phlogopite, $\mathrm{KMg}_{3}\left(\mathrm{Si}_{3} \mathrm{Al}\right) \mathrm{O}_{10}(\mathrm{~F}, \mathrm{OH})_{2}$ and clinochlore (sheridanite), $(\mathrm{MgFe})_{5} \mathrm{Al}\left(\mathrm{Si}_{3} \mathrm{Al}\right) \mathrm{O}_{10}(\mathrm{OH})_{8}$ are collected from various localities in the Republic of Macedonia.
\end{abstract}

Key words: minerals; X-ray powder diffraction; vibrational (infrared and Raman) spectroscopy

\section{INTRODUCTION}

Various techniques for mineral detection, identification, differentiation and characterization have been developed during the last few decades. Very frequently used among them are X-ray powder diffraction (XRPD) [1-3], Fourier-transform infrared spectroscopy (FTIR) $[2,4,5]$ and Raman [5-7] vibrational spectroscopy (only a selection of the relevant references is given above). All these techniques have their own advantages and imperfections and therefore it is strongly recommendable to use them complementary rather than competi- 
tive. Sometimes, however, it is necessary to use only one of the above mentioned (or other non-mentioned) techniques.

Here, some of the advantages and imperfections in the cases when the $\mathrm{X}$-ray powder diffraction, Fourier transform infrared or Raman vibrational spectroscopy are used as a separated techniques in the process of the mineral detection, identification, discrimination and characterization are presented. The characterization is based on the comparison of the results of our study with the corresponding literature data for the analogous mineral species originating from other localities in the world.

\section{EXPERIMENTAL}

Single grains of the minerals collected from various localities in the Republic of Macedonia were carefully picked up under a microscope and then powdered.

Philips Analytical X-ray diffractometer PW 3710 was used for X-ray powder diffraction (step $0.01^{\circ}$, time per step $2.5 \mathrm{~s}$ ). Generator with $50 \mathrm{kV}$ and current $30 \mathrm{~mA}$ were employed as a source for $\mathrm{CuK \alpha}$ radiation. The unit cell parameters were calculated from their X-ray diffraction pattern using CRYSFIRE software [8]. The obtained values were refined using CHECKCELL [9] (a modified version of CELREF for analyzing the solutions given by the CRYSFIRE).

The FT infrared spectra of the studied samples were recorded on Perkin-Elmer FT IR system 2000 interferometer using the KBr pellet method.

The Raman spectra were recorded on four instruments: computerized Dilor Z24 triple dispersive monochromator with Coherent Innova 400 argon ion laser operating at $514.5 \mathrm{~nm}$ for excitation, micro-Raman multichannel spectrometer - Horiba Jobin Yvon LabRam Infinity $(f \times 100)$ operating at $532 \mathrm{~nm}$ laser line obtained from a Nd-YAG frequency-double laser; Bruker FT Raman model 106/S connected to FT IR interferometer Equinox 55 with $1064 \mathrm{~nm}$ line of Nd-YAG frequency laser; Renishaw micro-Raman 1000 spectrometer equipped with a Peltier cooled CCD camera and Leica microscope $(f \times 50)$, the Raman effect being excited using the $514 \mathrm{~nm}$ line of an air cooled $\mathrm{Ar}^{+}$laser by Melles Griot.

The measurements were carried out at a room temperature (RT) and GRAMS/32 software [10] package was applied for the spectral manipulations. 
Chemical composition of the minerals was determined by electron microprobe analyzer (EMPA) CAMECA. The presented results represent the average values obtained from three different points.

\section{RESULTS AND DISCUSSION}

\subsection{Advantages of XRPD over vibrational spectroscopy}

Rutile, $\mathrm{TiO}_{2}$

The X-ray powder diffraction diagram of the studied rutile sample from Veselčani was recorded for the purpose of its identification. The most intense registered maxima in the studied powder diagram are listed in Table 1 [11] and were compared with the corresponding maxima in the diagram of natural rutile sample [12]. The comparison has shown that the X-ray powder pattern of the natural rutile taken from the literature (Table 1), are practically identical with the studied diagram. The results of the X-ray powder pattern analysis enable straightforward identification of the studied mineral sample as rutile.

Four IR active modes are registered in the studied far IR spectrum of rutile sample at $600,528,398$ and $334 \mathrm{~cm}^{-1}$ (Fig. 1) [11].

It should be taken into account, however, that the spectrum of rutile is extremely sensitive to size shape and other preparation conditions of the sample (see Fig. 2) [13, 14]. This effect is due to the high refraction index and is predominantly expressed in the IR rather than in the corresponding Raman spectrum [13].

Thus, the number of the registered bands in the literature is enlarged and causes broadening of the spectral region where the corresponding bands are expected to appear. Therefore, it could be concluded that the identification of the minerals with high polarizability index by FT IR spectroscopy should be justified even in the cases when rather expressed extent of band shifting is observed.

The characterization of the studied mineral sample shows that XRPD is certainly more reliable technique for identification of the studied rutile sample compared to the FT IR spectroscopy.

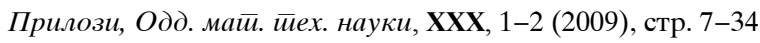


Ta ble 1

The most intense maxima in the X-ray diagram of rutile from Veselčani compared to the literature data (peak hunt: $1.5 \%$ )

\begin{tabular}{lcc|c}
\hline \hline & This work & & Berry \& Thompson, 1962 [10] \\
\hline$h k l$ & $I / I_{0}$ & $d_{\exp }(\AA)$ & $d_{\exp }(\AA)$ \\
\hline 110 & 100 & 3.21 & $3.24_{10}$ \\
101 & 32 & 2.46 & $2.49_{5}$ \\
200 & 8 & 2.23 \\
111 & 15 & 2.17 & $2.29_{1 / 2}$ \\
210 & 7 & 2.04 \\
211 & 33 & 1.68 & $2.18_{3}$ \\
220 & 9 & 1.62 & $2.05_{1 / 2}$ \\
002 & 6 & 1.47 & $1.687_{7}$ \\
130 & 6 & 1.45 & $1.621_{3}$ \\
031 & 12 & 1.35 & $1.473_{1}$ \\
112 & 8 & 1.34 & $1.451_{1}$ \\
321 & 5 & 1.18 & $1.354_{4}$ \\
222 & 5 & 1.09 & $1.344_{1}$ \\
141 & 5 & 1.04 & $1.169_{1}$ \\
\hline \hline
\end{tabular}

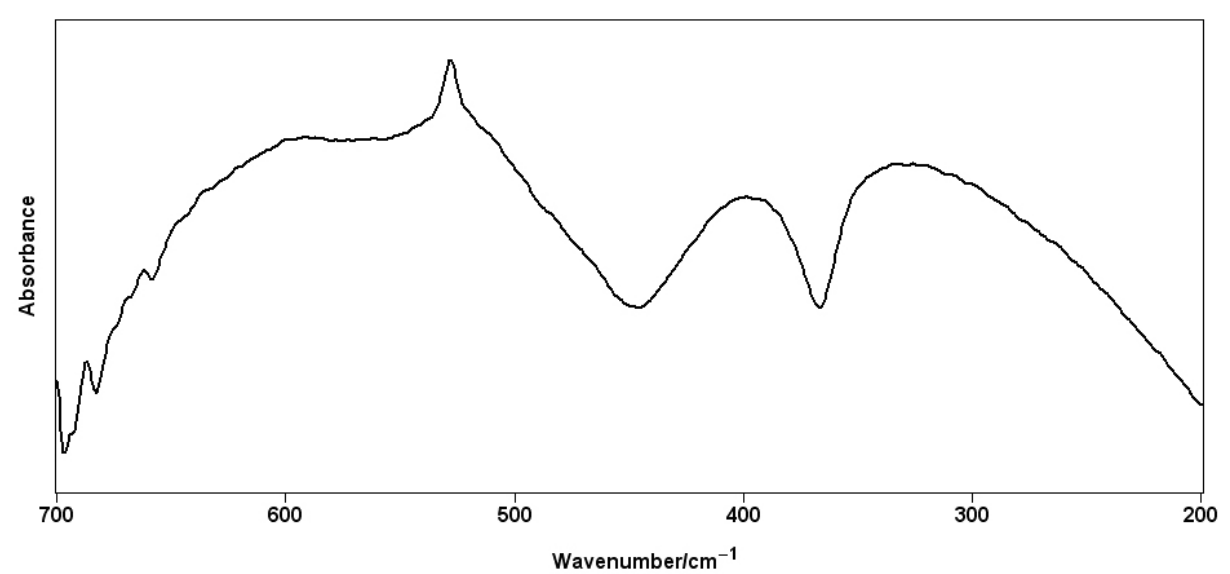

Fig. 1. The far IR spectrum of rutile from Veselčani 


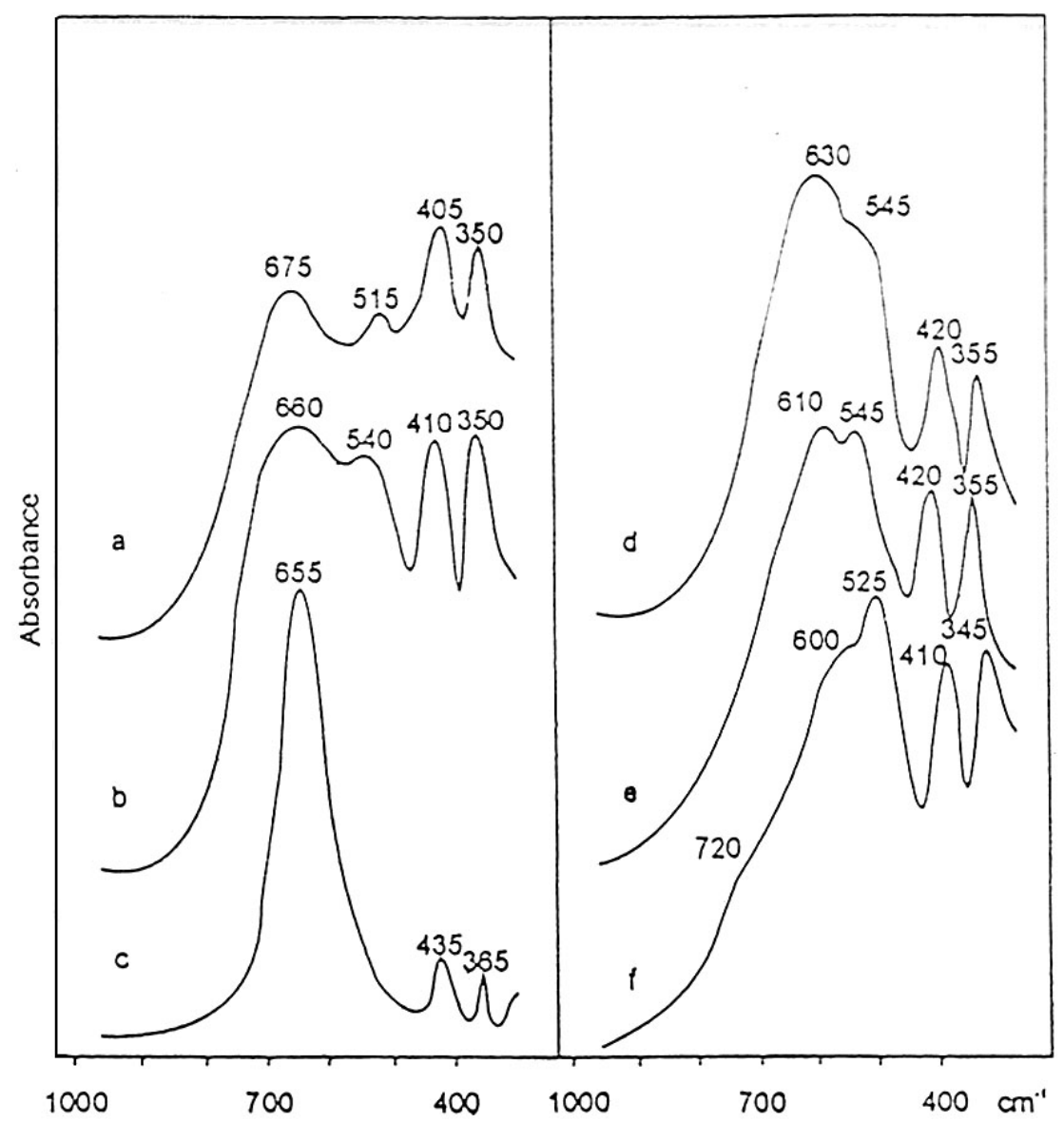

Fig. 2. The IR spectra of various powdered rutile samples [13, 14]

Hematite, $\mathrm{Fe}_{2} \mathrm{O}_{3}$

The X-ray diagrams of the investigated hematite samples from Damjan and Ržanovo (Fig. 3) were recorded in order to verify the mineral identification. As seen from Fig. 3 and Tables 2 and 3, both X-ray powder pattern are similar, excluding the appearance of a series of the peaks with the $d$-values higher than $4 \AA$ in the X-ray pattern of hematite from Ržanovo [11]. Regarding 
the high content of $\mathrm{Mg}$ and $\mathrm{Si}$ in the Ržanovo sample (Table 1 in ref. 11), the peaks at $d=9.03,4.67$ and $3.05 \AA$ are compliant with talc maxima registered at $9.35,4.59$ and $3.12 \AA[12]$, whereas the maxima registered at $6.88,3.51$ and $2.27 \AA$ correspond to the presence of orthochrysotile impurities $(7.10,3.55$ and $2.33 \AA$; see Table 3).
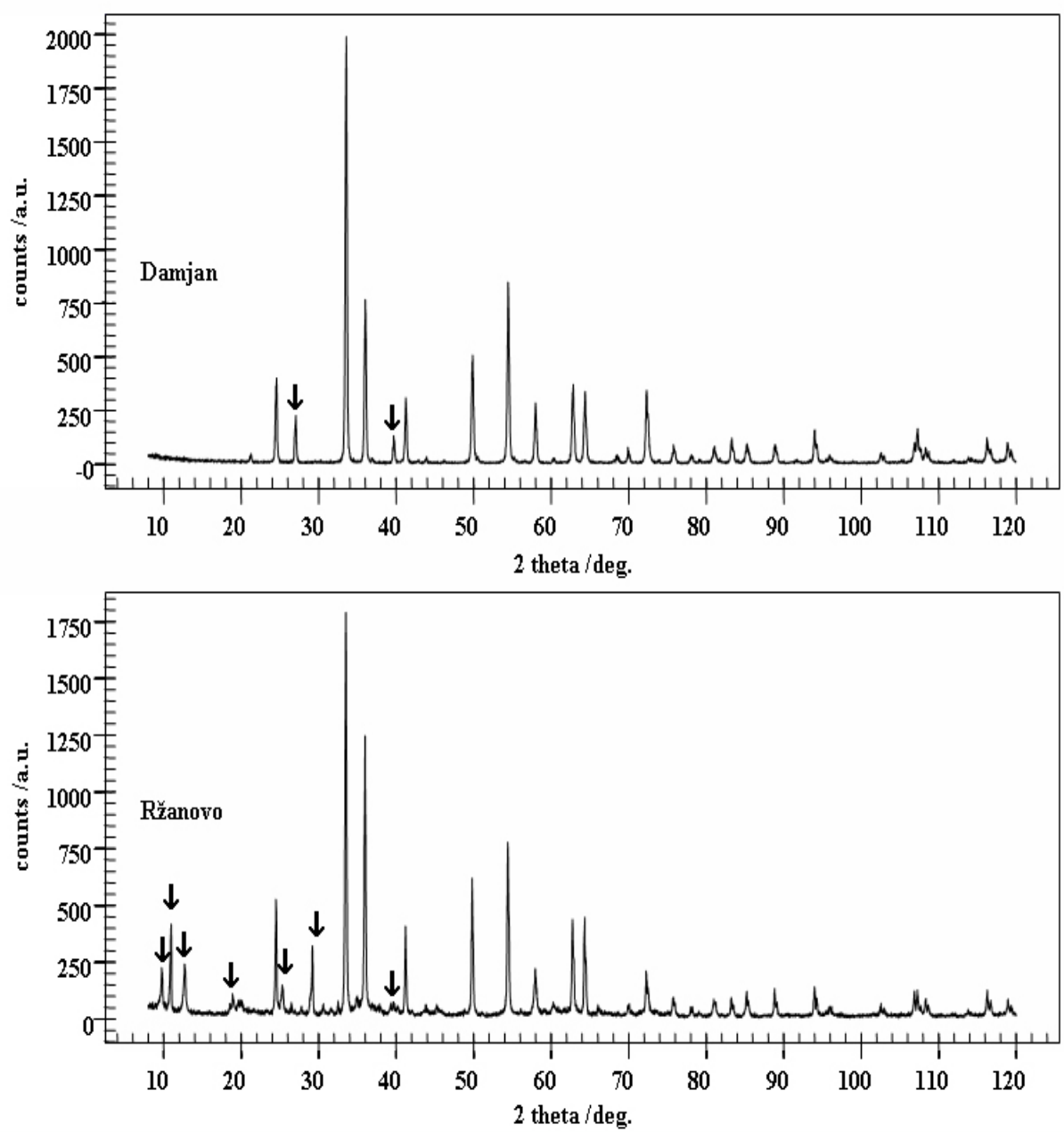

Fig. 3. X-ray powder pattern of hematite from Damjan and Ržanovo 
T a b 1 e 2

The most intensive maxima in the X-ray diagram of hematite from Damjan compared to the literature data (peak hunt: $2 \%$ )

\begin{tabular}{|c|c|c|c|c|}
\hline \multicolumn{3}{|c|}{ This work } & \multirow{2}{*}{$\begin{array}{c}\text { Berry \& Thompson, } \\
1962[12] \\
d_{\exp }(\AA)\end{array}$} & \multirow{2}{*}{$\begin{array}{l}\text { Impurity }^{\mathrm{a}} \\
d_{\exp }(\AA)\end{array}$} \\
\hline$h k l$ & $I / I_{0}$ & $d_{\exp }(\AA)$ & & \\
\hline \multirow[t]{2}{*}{012} & 22 & 3.61 & $3.68_{3}$ & \\
\hline & 14 & 3.28 & - & $3.34_{x}-$ Quartz \\
\hline 104 & 100 & 2.66 & $2.69_{10}$ & \\
\hline \multirow[t]{2}{*}{110} & 40 & 2.49 & $2.52_{8}$ & \\
\hline & 9 & 2.27 & - & $2.28_{4}-$ Quartz \\
\hline 113 & 17 & 2.18 & $2.21_{4}$ & \\
\hline 024 & 27 & 1.83 & $1.843_{6}$ & \\
\hline 116 & 44 & 1.68 & $1.697_{7}$ & \\
\hline 122 & 15 & 1.59 & $1.604_{3}$ & \\
\hline 214 & 20 & 1.48 & $1.488_{5}$ & \\
\hline 300 & 19 & 1.45 & $1.457_{5}$ & \\
\hline 208 & 6 & 1.34 & $1.351_{1}$ & \\
\hline 10.10 & 19 & 1.30 & $1.313_{4}$ & \\
\hline 217 & 7 & 1.25 & $1.261_{2}$ & \\
\hline 312 & 7 & 1.18 & $1.192_{2}$ & \\
\hline 02.10 & 7 & 1.16 & $1.166_{2}$ & \\
\hline 134 & 7 & 1.14 & $1.143_{4}$ & \\
\hline 226 & 7 & 1.10 & $1.079_{1 / 2}$ & \\
\hline 21.10 & 10 & 1.05 & $1.058_{5}$ & \\
\hline 232 & 5 & 0.99 & $0.99_{3}$ & \\
\hline
\end{tabular}

${ }^{a}$ According to Berry and Thompson, 1962 [12]

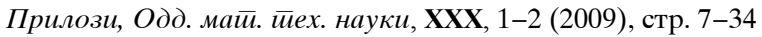


Ta b 1 e 3

The most intense maxima in the X-ray diagram of hematite from Ržanovo compared to the literature data (peak hunt: $3 \%$ )

\begin{tabular}{|c|c|c|c|c|}
\hline \multicolumn{3}{|c|}{ This work } & \multirow{2}{*}{$\begin{array}{c}\text { Berry \& Thompson, } \\
1962[12] \\
d_{\exp }(\AA)\end{array}$} & \multirow{2}{*}{$\begin{array}{c}\text { Impurities }^{\mathrm{a}} \\
\frac{d_{\exp }(\AA)}{(\AA)}\end{array}$} \\
\hline$h k l$ & $I / I_{0}$ & $d_{\exp }(\AA)$ & & \\
\hline & 12 & 9.03 & - & $9.35_{x}-$ Talc \\
\hline & 25 & 7.99 & - & $?$ \\
\hline & 15 & 6.88 & - & $7.10_{x}-$ Orthochrysotile \\
\hline & 8 & 4.67 & - & $4.59_{6}-$ Talc \\
\hline \multirow[t]{3}{*}{012} & 29 & 3.62 & $3.68_{3}$ & \\
\hline & 10 & 3.51 & - & $3.55_{7}-$ Orthochrysotile \\
\hline & 20 & 3.05 & - & $3.12_{4}-$ Talc \\
\hline 104 & 100 & 2.67 & $2.69_{10}$ & \\
\hline \multirow[t]{2}{*}{110} & 70 & 2.49 & $2.52_{8}$ & \\
\hline & 6 & 2.27 & - & $2.33_{8}-$ Orthochrysotile \\
\hline 113 & 25 & 2.19 & $2.21_{4}$ & \\
\hline 024 & 36 & 1.83 & $1.843_{6}$ & \\
\hline 116 & 45 & 1.68 & $1.697_{7}$ & \\
\hline 122 & 14 & 1.59 & $1.604_{3}$ & \\
\hline 214 & 26 & 1.48 & $1.488_{5}$ & \\
\hline 300 & 26 & 1.45 & $1.457_{5}$ & \\
\hline 208 & 6 & 1.34 & $1.351_{1}$ & \\
\hline 10.10 & 13 & 1.31 & $1.313_{4}$ & \\
\hline 217 & 7 & 1.25 & $1.261_{2}$ & \\
\hline 312 & 5 & 1.19 & $1.192_{2}$ & \\
\hline 02.10 & 8 & 1.16 & $1.166_{2}$ & \\
\hline 134 & 9 & 1.14 & $1.143_{4}$ & \\
\hline 226 & 10 & 1.10 & $1.106_{4}$ & \\
\hline 21.10 & 10 & 1.05 & $1.058_{5}$ & \\
\hline 232 & 6 & 0.99 & $0.99_{3}$ & \\
\hline
\end{tabular}

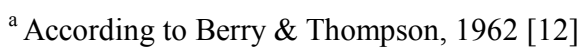


The hematite spectra of the samples from Damjan and Ržanovo (Fig. 4) in the far infrared region were studied. As seen, spectra are similar and strongly indicate that the investigated samples belong to the same mineral. All bands in our spectra are covered (see Table 3 in ref. 11) by analogue ones in the spectra published by Serna et al. [15]. The expressed strong similarity between the IR spectra of the two studied hematite samples from Damjan and Ržanovo localities makes impossible to registry the presence of various types and quantities of the already detected impurities by XRPD technique.

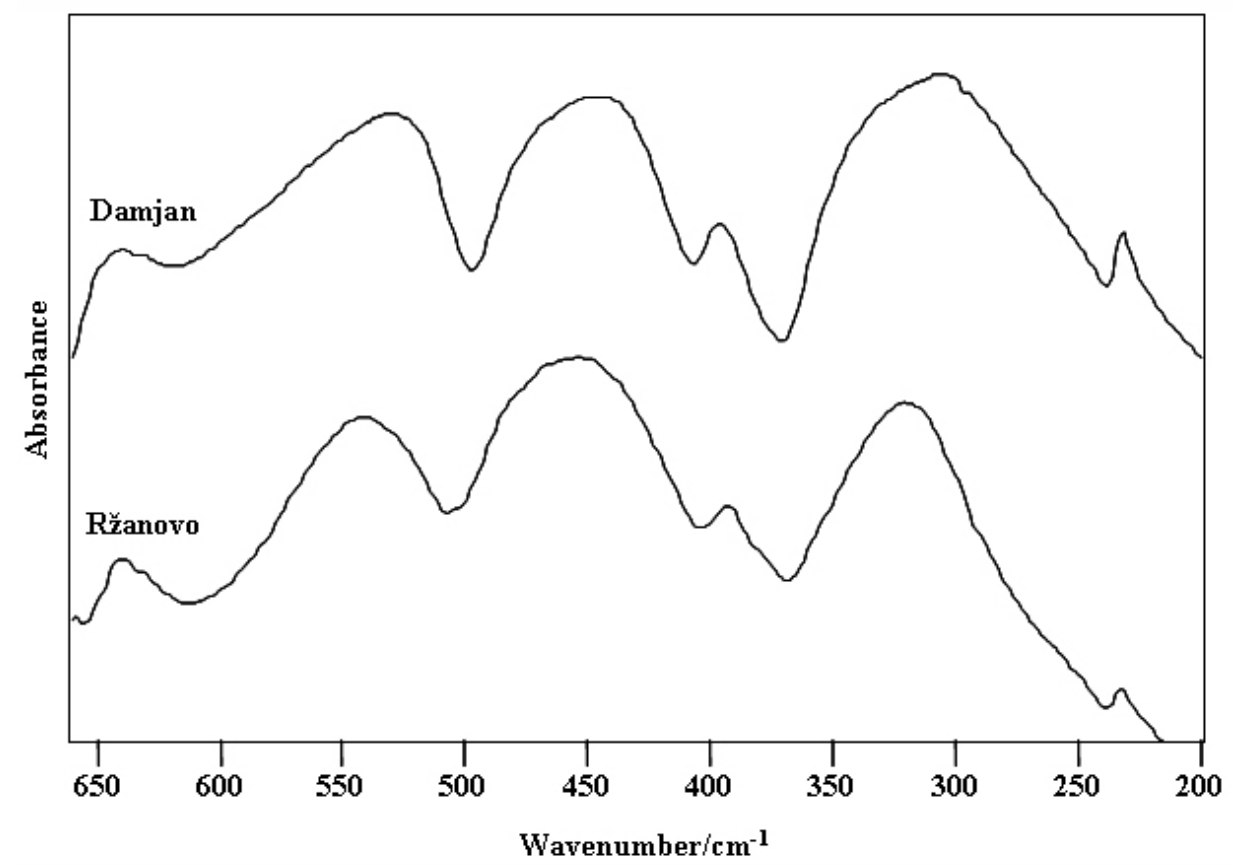

Fig. 4. The far IR spectra of hematite from Damjan and Ržanovo

It is again evidently that, compared to the FT IR method, the XRPD is more reliable technique for the purpose of the detection of the presence of various types of impurities in the studied two hematite samples. 
3.2. Same level quality results by both XRPD and vibrational techniques

Almandine, $\mathrm{Fe}_{3} \mathrm{Al}_{2}\left(\mathrm{SiO}_{4}\right)_{3}$ and spessartine, $\mathrm{Mn}_{3} \mathrm{Al}_{2}\left(\mathrm{SiO}_{4}\right)_{3}$

The study of the X-ray powder diffraction pattern of almandine from Staro Bonče and spessartine from Lojane (Fig. 5) (see also Tables 24 and 25 in ref. 16) has shown that they are in a complete agreement with the corresponding literature data [17]. In spite of the practical identity between the X-ray diagrams of the two studied garnet mineral samples (Fig. 5), there are two weak peaks in the almandine diagram ( $d$-values of 3.3313 and $0.9342 \AA$ ) which are absent in the diagram of the spessartine analoque. They enable the discrimination between these two isomorphous garnet minerals using the X-ray powder diffraction.

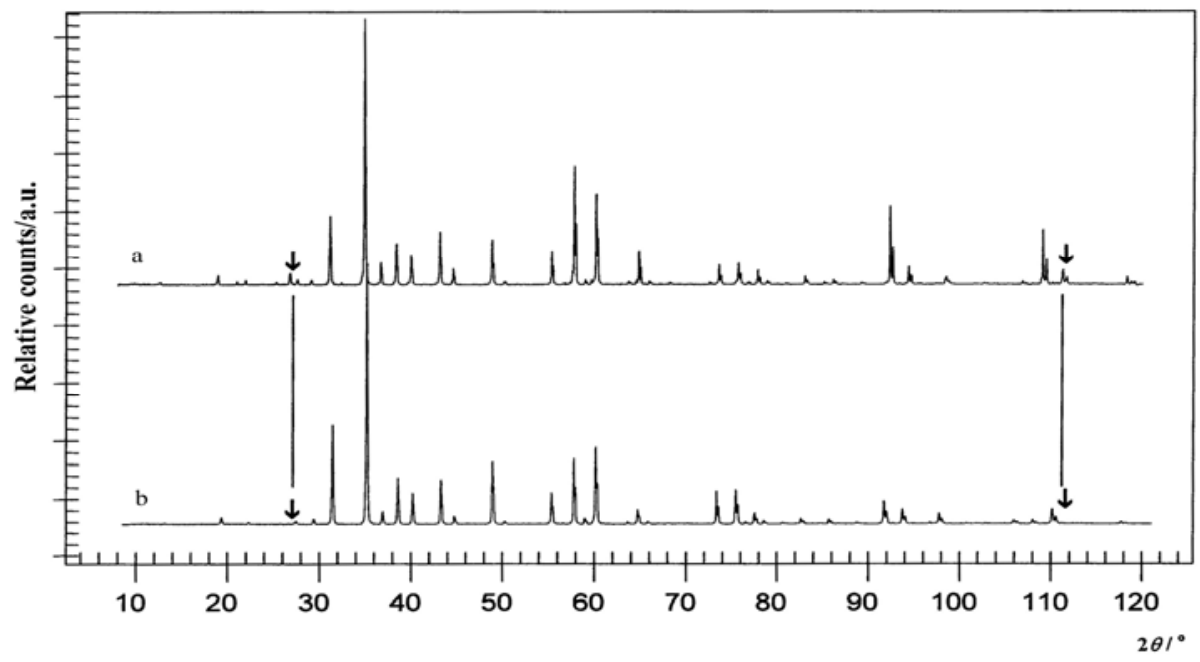

Fig. 5. X-ray powder pattern of almandine from Staro Bonče (a) and spessartine from Lojane (b). The peaks present in almandine which are absent in spessartine diagram are denoted by arrows.

In order to relate the vibrational and the crystallographic characteristics of the isomorphous minerals almandine (from Staro Bonče) and spessartine (from Lojane), their powder IR absorption spectra (Fig. 6) were studied. As 
seen from Fig. 6, the IR spectra of almandine and spessartine are practically identical and, in general, in accordance with the corresponding literature data (see Tables 20 and 21 in ref. 16).

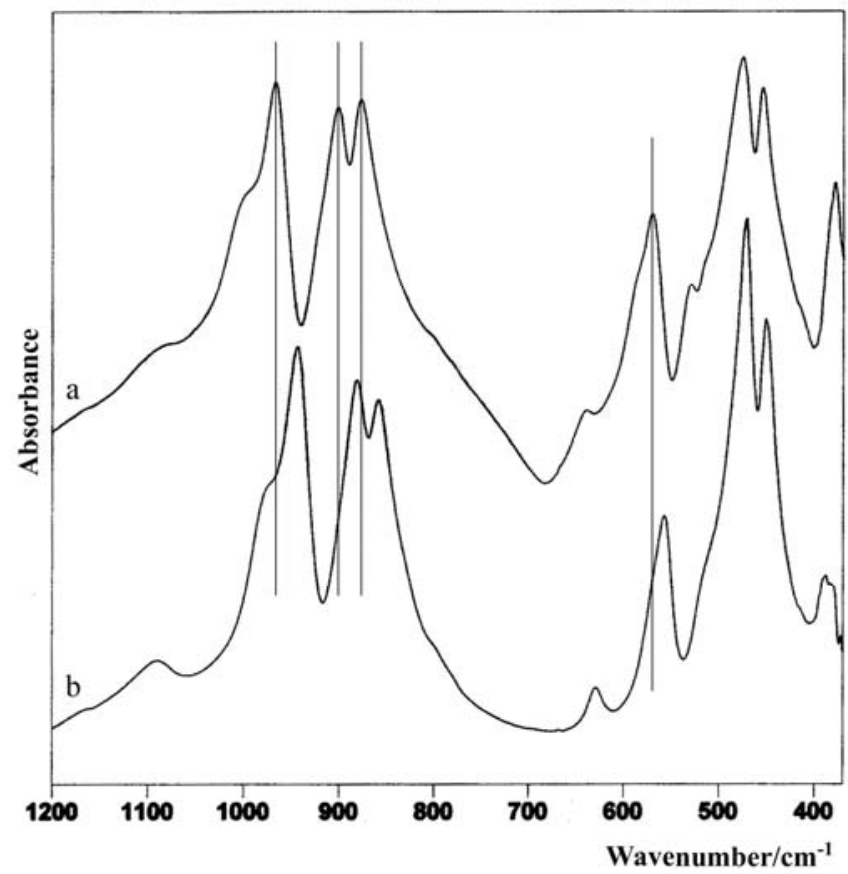

Fig. 6. Infrared spectra of almandine from Staro Bonče (a) and spessartine from Lojane (b)

It should be pointed out that, compared to the corresponding modes in the spectrum of almandine, a frequency decreasing trend was registered for the $v_{3}$ modes and for the bands in the $650-500 \mathrm{~cm}^{-1}$ region of the spessartine spectrum (Fig. 6). It means that the vibrational frequencies of the almandine having smaller unit cell volume $\left(1533.2 \AA^{3}\right)$ are, in general, higher than those of spessartine whose unit cell volume is larger $\left(1565.7 \AA^{3}\right)$ [18]. In addition to XRPD, it enables to discriminate between these two isomorphous minerals by using the FT IR method.

The study of the dispersive (excitation line $514 \mathrm{~nm}$ ) and FT-Raman (excitation line $1064 \mathrm{~nm}$ ) spectra of almandine (Figure 2 in ref. 18) has shown 
that they are, to some extent, similar, but show some significant differences (Table 4 in ref. 18). It suggests that one should be careful during their use for identification purposes as well as for spectra-structure correlations [18]. In fact, all bands observed in the dispersive Raman spectrum are present in the FT-counterpart, where two additional strong bands at 607 and $446 \mathrm{~cm}^{-1}$ were registered. Since the dispersive Raman spectrum showed a closer similarity with the corresponding spectrum of the isomorphous spessartine analogue (Fig. 23 in ref. 16), it was presumed that, more likely, some structural changes appear during the recording of the almandine FT-Raman spectrum $[16,18]$. Later it was shown [19] that the strong bands in the FT-Raman spectrum of almandine (at 607 and $446 \mathrm{~cm}^{-1}$ ) are fluorescence bands that appear from the traces of rare earth impurities in the sample (Figures 7 and 8). Therefore, the use of dispersive Raman instruments are more convenient for mineral suites but when implying the FT-Raman technique it is more than recommendable to extend the spectral range in the Anti-Stokes side, as well.

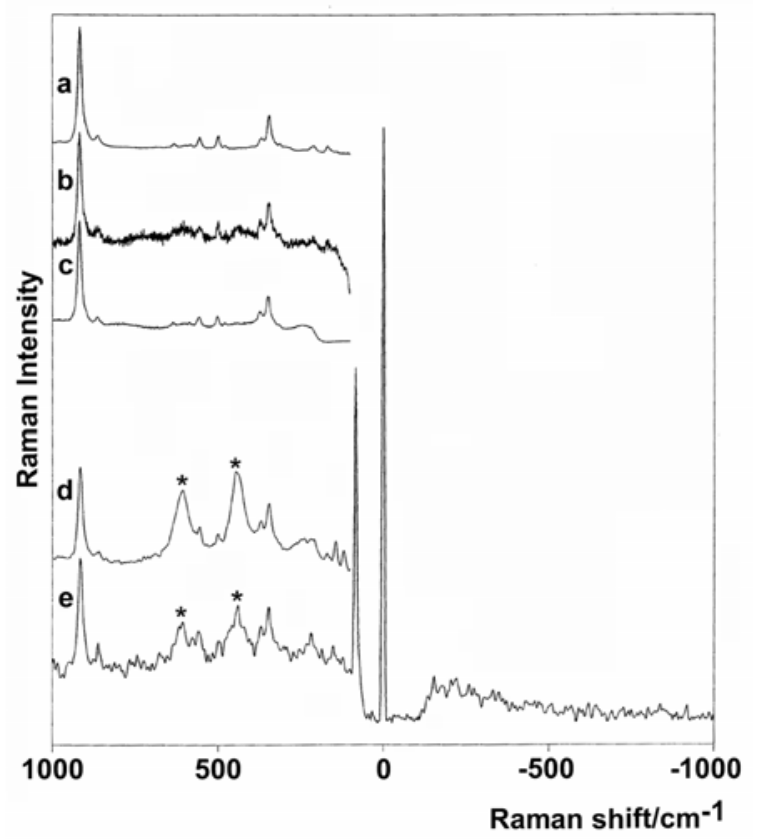

Fig. 7. Dispersive Raman spectra of almandine from Staro Bonče (a, b, c) obtained with 532, 488 and $514.5 \mathrm{~nm}$ excitation line, respectively. FT-Raman spectra of almandine in Stokes (d) and in both Stokes and Anti-Stokes side (e) obtained with $1064 \mathrm{~nm}$ line. The fluorescence bands at 446 and $607 \mathrm{~cm}^{-1}$ in the FT-Raman spectra are denoted by asterisk. 


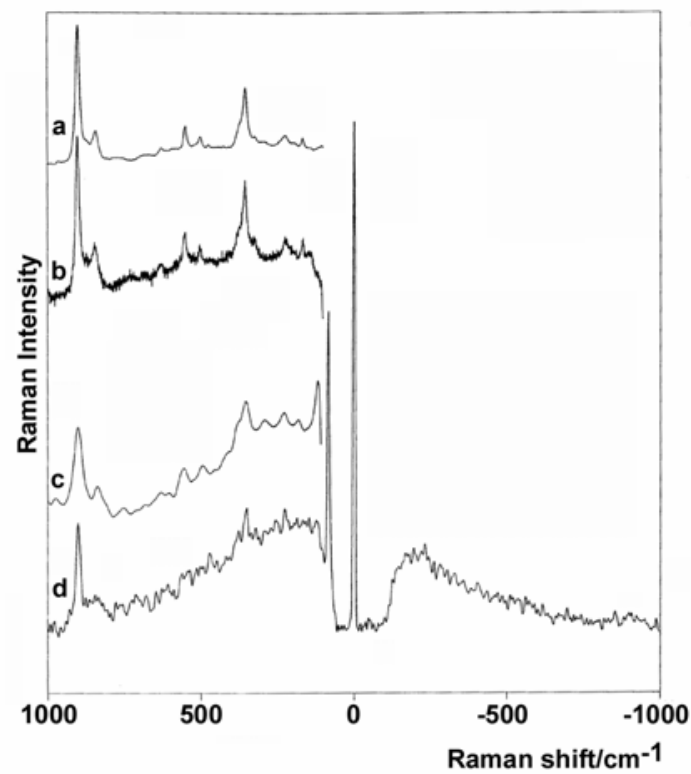

Fig. 8. Dispersive Raman spectra of spessartine from Lojane (a, b) obtained with 532 and $488 \mathrm{~nm}$ excitation line, respectively. FT-Raman spectra of spessartine in Stokes (c) and in both Stokes and Anti-Stokes side (d) obtained with $1064 \mathrm{~nm}$ line.

The above mentioned results strongly indicate that, if not treated in the correct manner, some of the registered bands in the FT-Raman vibrational spectra could be erroneously ascribed to the fundamental Raman bands leading to the wrong conclusions in the process of the mineral identification. It means that even sub-techniques (dispersive and FT-Raman spectroscopy) belonging to the same vibrational method (Raman) have their own advantages and imperfections and therefore it is also strongly recommendable to use them complementary rather than competitive.

\section{Limonite, $\mathrm{FeO}(\mathrm{OH})$}

Generally, the term limonite is used for mixtures of various iron oxide and hydroxide minerals, the most common among them being goethite, $\alpha$ FeOOH and lepidocrocite, $\gamma$-FeOOH.

The study of the infrared spectra of the collected two goethite samples from Pehčevo and Alšar has shown the drastic intensity decreasing of the two 
strong bands at 1085 and $1037 \mathrm{~cm}^{-1}$ is found in the spectrum of limonite from Alšar compared to the corresponding spectrum of the sample from Pehčevo (Fig. 9). The rest of the bands in the spectrum did not change having almost the same intensity and frequencies being in a good agreement with literature data (see Table 15 in ref. 11). It was taken as a strong indication that the studied limonite sample is, in fact, a mixture of goethite and another mineral, rather than lepidocrocite.

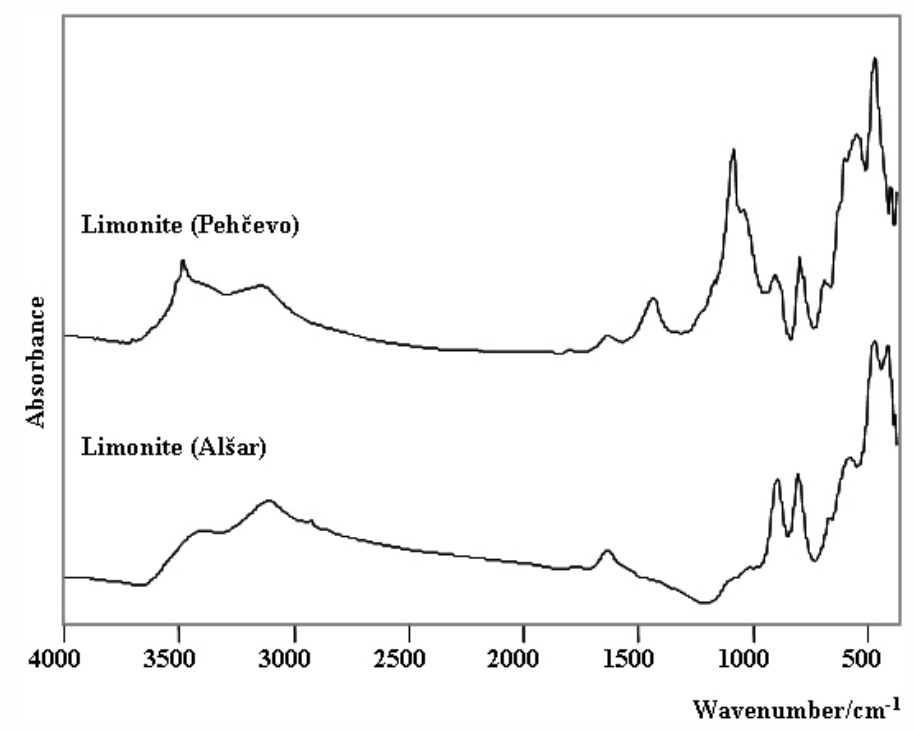

Fig. 9. The mid IR spectra of limonite from Pehčevo and Alšar

The performed chemical analysis has shown that the limonite sample from Pehčevo contains w.t. $23.65 \% \mathrm{SiO}_{2}$ (Table 1 of ref. 11). Significantly lower content of $\mathrm{SiO}_{2}$ was found in the limonite sample from Alšar. In order to identify the nature of the present silicate mineral in the limonite sample from Pehčevo the IR spectra of both limonite samples and quartz were compared (Fig. 10). The comparison has shown that the bands at 1085, 1037, 779, 683 and $470 \mathrm{~cm}^{-1}$ in the spectrum of limonite from Pehčevo arise from the quartz impurities whereas the sample from Alšar is in fact goethite with a low quantity of quartz impurities (Fig. 10). Such result is not unexpected having in mind Pehčevo locality mineralization consisted of quartzlatite breccia cemented with the limonite body. 


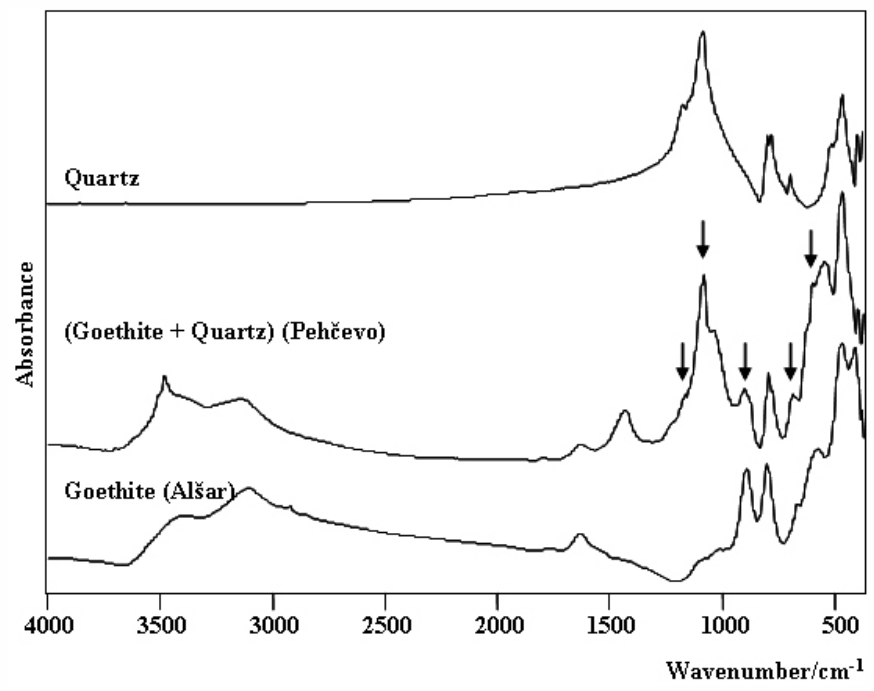

Fig. 10. The mid IR spectra of quartz, limonite from Pehčevo and goethite from Alšar

In order to confirm the above presumption, the X-ray powder pattern of the studied limonite (Pehčevo), goethite (Alšar) and quartz samples were recorded (Figures 11 and 12).

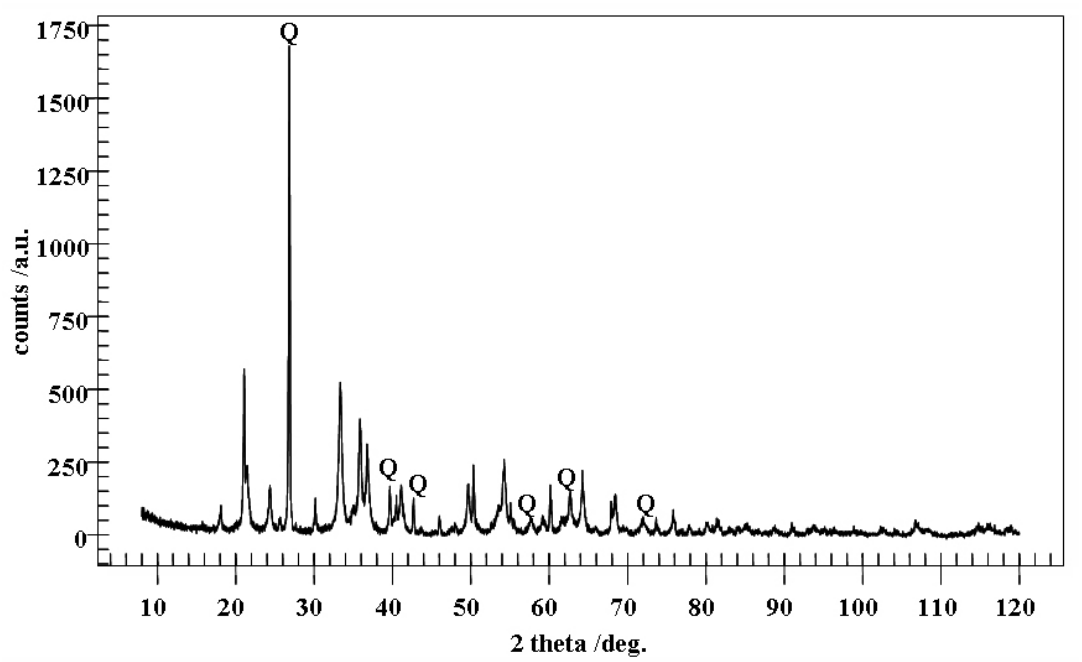

Fig. 11. X-ray powder pattern of limonite (goethite and quartz) from Pehčevo (Q = quartz)

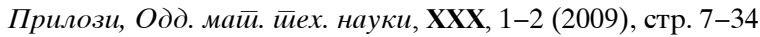




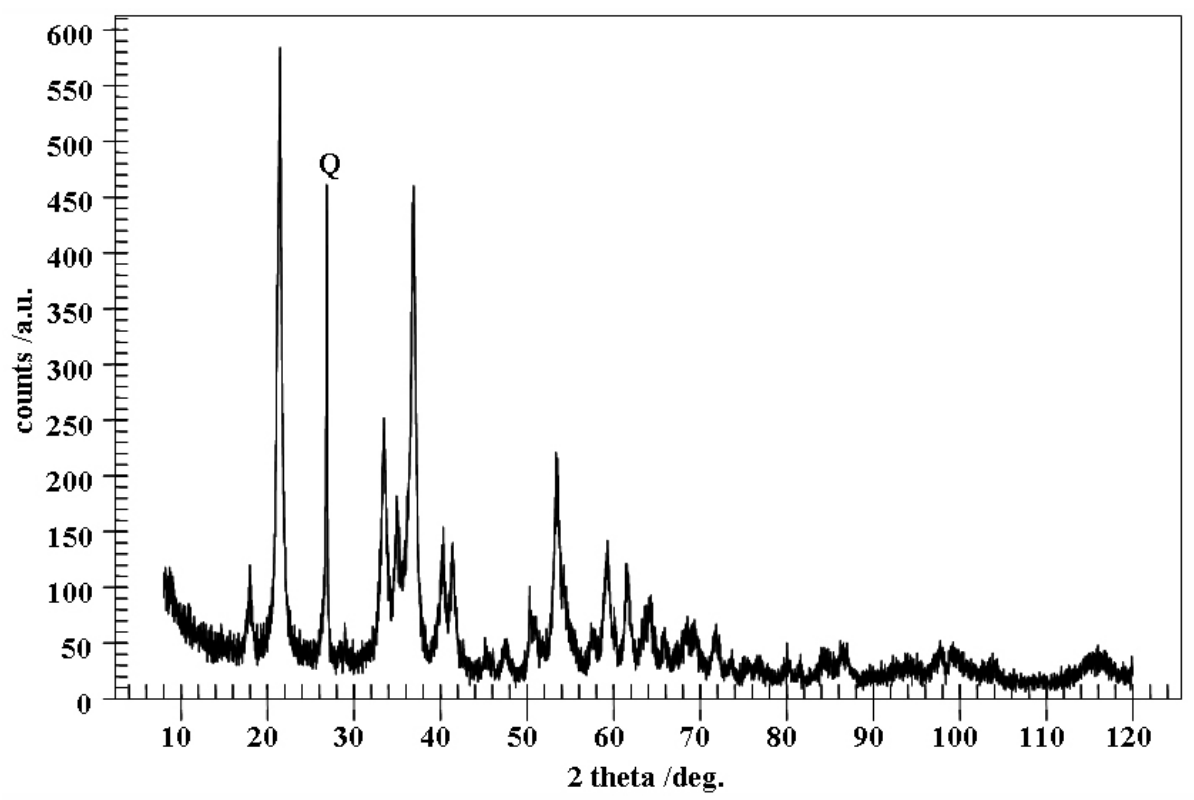

Fig. 12. X-ray powder pattern of limonite (goethite) from Alšar $(Q=$ quartz)

The summarized results of the X-ray powder analysis of limonite compared with the corresponding literature data for goethite and quartz are shown in Table 16 of ref. 11. Obviously, the most intensive maximum for the studied limonite sample at $d=3.31 \AA$ is accompanied with the corresponding maximum of quartz at $d=3.34 \AA$ [12]. The limonite diagram is additionally associated with three other peaks $(2.46,2.22$ and $1.54 \AA$ ), typical only for quartz $(2.46,2.23$ and $1.542 \AA)$. No doubt that a high content of quartz impurity is present in the studied limonite sample form Pehčevo. On the other hand, the goethite form of the studied sample is manifested by the following powder Xray peaks registered at $d$-values $2.68,2.56,2.48,2.44,2.18,1.71,1.69,1.56$, $1.51,1.48$ and $1.37 \AA$. The remaining maxima are common for both minerals and appear at very similar $d$-values (see Table 16 in ref. 11).

The X-ray pattern of limonite sample from Alšar shows much higher extent of similarity with the corresponding data for mineral goethite given in the literature [12] (see Table 17 in ref. 11). Exception is the intensive peak at $d$ $=3.31 \AA$ due to the quartz impurities in the sample. Its appearance as the strongest maximum in quartz diagram is expected [12]. 
Ferojohannsenite, $\mathrm{Ca}(\mathrm{Fe}, \mathrm{Mn}) \mathrm{Si}_{2} \mathrm{O}_{6}$

The study of the FT IR spectrum of the ferrojohannsenite from Sasa [20] has shown that, besides the expected fundamental bands from ferrojohannsenite, additional maxima due to the presence of quartz and carbonate (calcite or siderite) impurities are registered (Fig. 13; see also Table 5 in ref. 20).

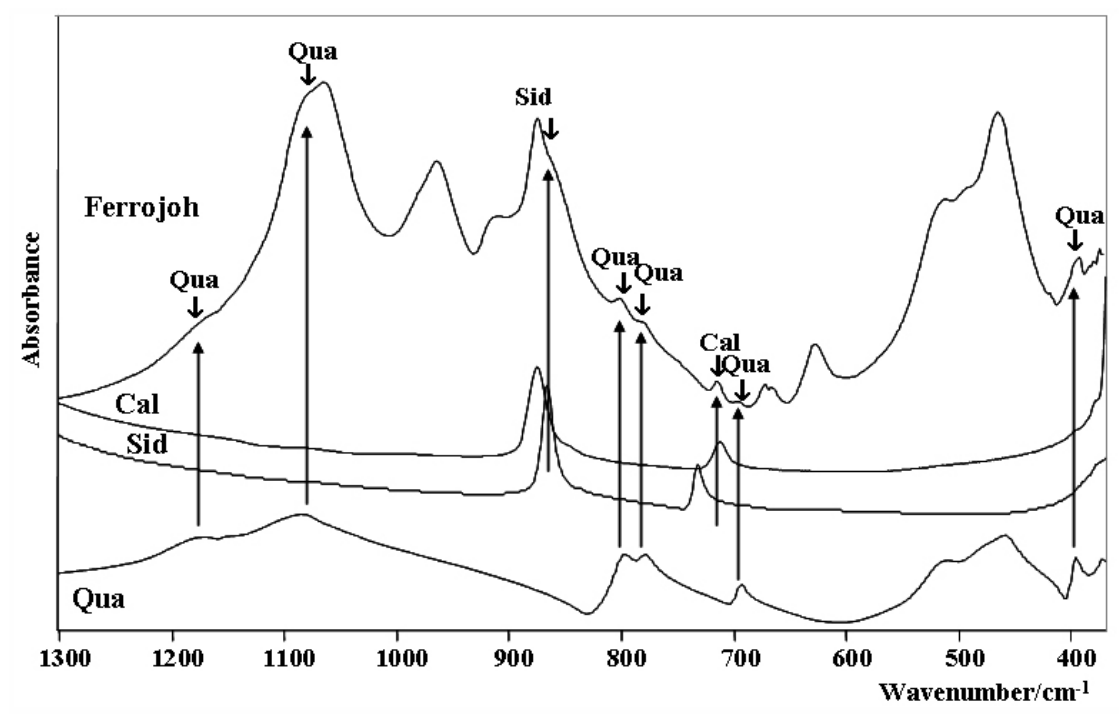

Fig. 13. The FT IR spectra of ferrojohannsenite (from Sasa), calcite, siderite and quartz $($ Ferrojoh $=$ ferrojohansenite; Qua $=$ quartz; $\mathrm{Sid}=$ siderite $;$ Cal $=$ calcite $)$

Additional bands, not typical for this type of mineral, were also observed in the ferrojohannsenite Raman spectrum (Fig. 14; see also Table 8 in ref. 20) [20]. Their wavenumbers and intensities agree well with the corresponding values registered in the Raman spectra of quartz and siderite or calcite.

The presence of quartz impurity in the studied ferrojohannsenite sample was also confirmed by the study of its X-ray powder pattern (Fig. 15 and Table 4; see also Table 3 in ref. 20). XRPD pattern also enabled to elucidate that the registered carbonate impurities by FT IR and Raman vibrational spectroscopy in fact arise from siderite. Namely, the observed maximum at $d=$ $2.7950 \AA$ most closely corresponds to the $d$ value $(2.789 \AA)$ of the most intense maximum in the X-ray powder diagram of siderite (Table 4) [17]. 


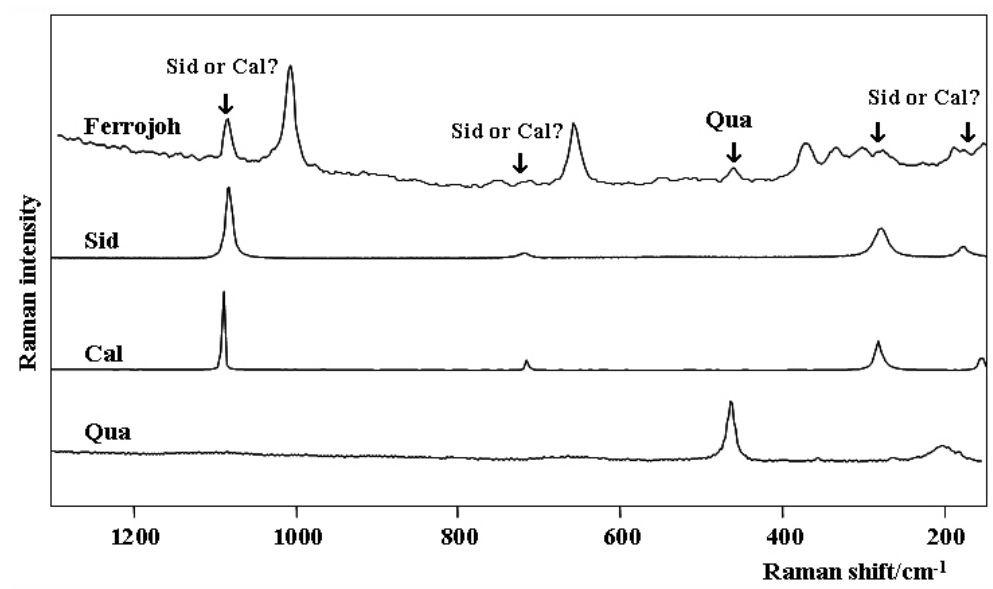

Fig. 14. Raman spectra of ferrojohannsenite (from Sasa), siderite, calcite and quartz $($ Ferrojoh $=$ ferrojohansenite; $\mathrm{Qua}=$ quartz; $\mathrm{Sid}=$ siderite $; \mathrm{Cal}=$ calcite $)$

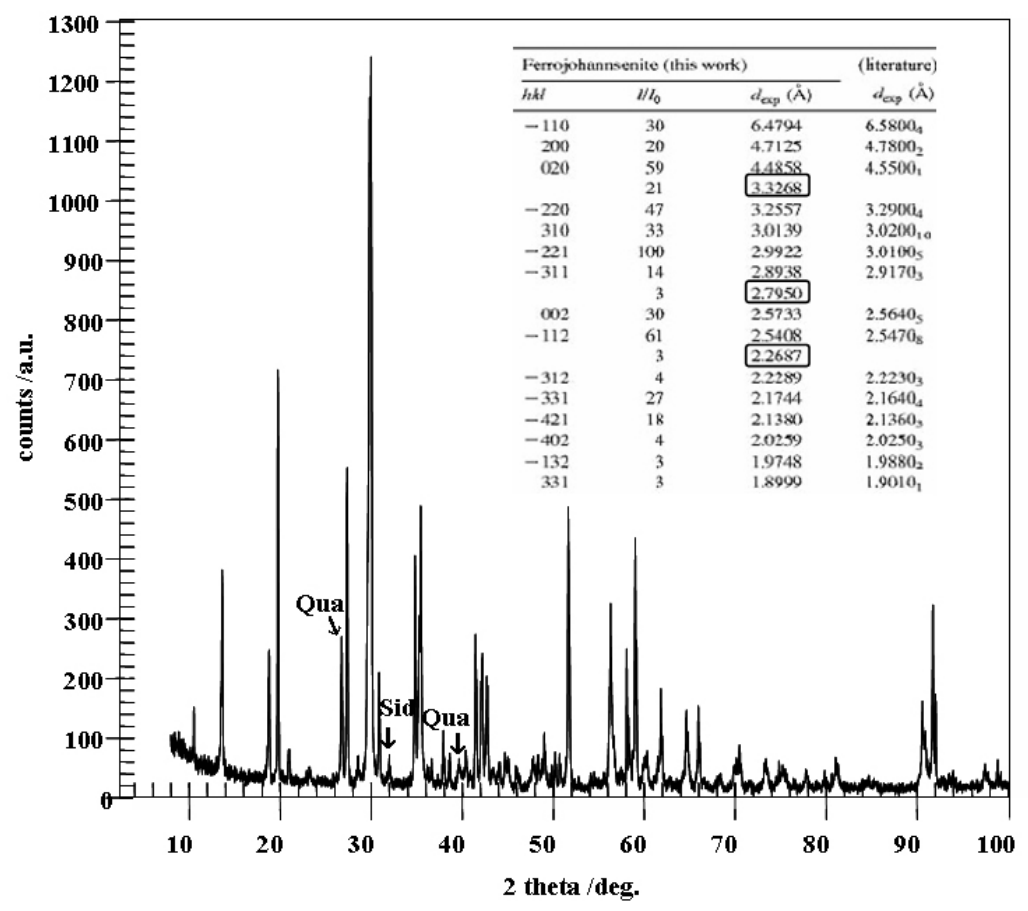

Fig. 15. Powder X-ray pattern of ferrojohannsenite from Sasa $($ Qua $=$ quartz; $\mathrm{Sid}=$ siderite $)$ 
T a b le 4

Some of the maxima in the X-ray powder diagram of ferrojohannsenite in the region of the d-values where quartz and siderite impurities are expected

\begin{tabular}{cccccccccccc}
\hline \hline \multicolumn{1}{c}{ QUARTZ, $\mathrm{SiO}_{2}$} & \multicolumn{1}{c}{ SIDERITE, $\mathrm{FeCO}_{3}$} \\
\hline 2 theta & $d(\mathrm{~A})$ & Int. & $h$ & $k$ & $l$ & 2 theta & $d(\mathrm{~A})$ & Int. & $h$ & $k$ & $l$ \\
\hline 26.639 & 3.343 & 100 & 1 & 0 & 1 & 32.065 & 2.789 & 100 & 1 & 0 & 4 \\
39.466 & 2.281 & 15 & 1 & 0 & 2 & 46.233 & 1.962 & 30 & 2 & 0 & 2 \\
50.138 & 1.818 & 15 & 1 & 1 & 2 & 52.878 & 1.730 & 45 & 1 & 1 & 6 \\
\hline \hline
\end{tabular}

Olivine, $(\mathrm{Mg}, \mathrm{Fe})_{2} \mathrm{SiO}_{4}$

The term olivine, $(\mathrm{Mg}, \mathrm{Fe})_{2} \mathrm{SiO}_{4}$ represents solid solutions of the isomorphous forsterite, $\mathrm{Mg}_{2} \mathrm{SiO}_{4}$, and fayalite, $\mathrm{Fe}_{2} \mathrm{SiO}_{4}$. The study of the IR spectrum of the olivine sample from Ržanovo $[16,18,21]$ showed that the band frequencies are much closer to the corresponding bands in the spectrum of forsterite, $\mathrm{Mg}_{2} \mathrm{SiO}_{4}$ (Fig. 16 and Table 5). The presence of two strong bands (at 417 and $608 \mathrm{~cm}^{-1}$ ) in the IR spectrum of forsterite, absent in the spectrum of fayalite may serve as a further aid to discriminate between the two end-members of olivine series. An additional discriminating feature is the lack of bands below $450 \mathrm{~cm}^{-1}$ in the fayalite spectrum being present in the spectrum of forsterite.

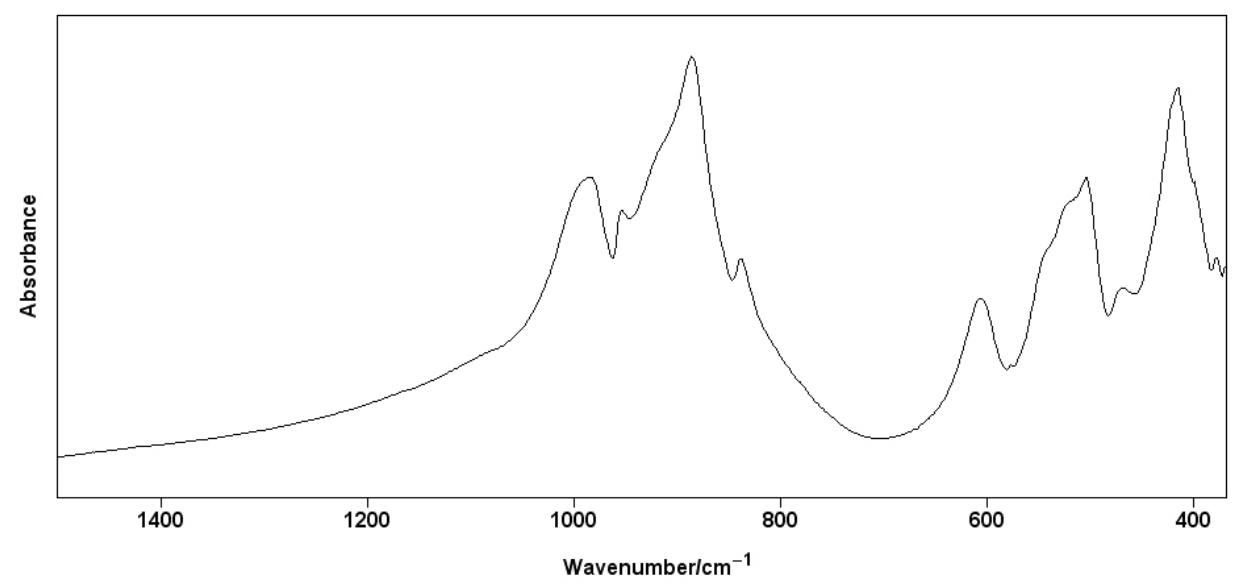

Fig. 16. FT IR spectra of olivine from Ržanovo (variety forsterite)

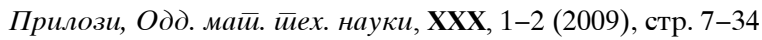


Table 5

Frequencies and intensities of the bands in the infrared spectrum of olivine from Ržanovo compared with the corresponding literature data (in $\mathrm{cm}^{-1}$ )

\begin{tabular}{ccccc}
\hline \hline \multirow{2}{*}{ This } & \multicolumn{2}{c}{ Tarte $[22]$} & \multicolumn{2}{c}{ Burns \& Huggins [23] } \\
work & $\mathrm{Mg}_{2} \mathrm{SiO}_{4}$ & $\mathrm{Fe}_{2} \mathrm{SiO}_{4}$ & $\mathrm{Mg}_{2} \mathrm{SiO}_{4}$ & $\mathrm{Fe}_{2} \mathrm{SiO}_{4}$ \\
\hline $379 \mathrm{vw}$ & $380 \mathrm{vw}$ & - & $378 \mathrm{vw}$ & - \\
$401 \mathrm{sh}$ & $402 \mathrm{sh}$ & - & $399 \mathrm{vw}$ & - \\
$417 \mathrm{vs}$ & $422 \mathrm{~s}$ & $420 \mathrm{sh}$ & $415 \mathrm{vs}$ & - \\
$470 \mathrm{w}$ & $465 \mathrm{~m}$ & $481 \mathrm{~s}$ & $469 \mathrm{w}$ & $472 \mathrm{~s}$ \\
$505 \mathrm{vs}$ & $510 \mathrm{vs}$ & $509 \mathrm{~m}$ & $506 \mathrm{vs}$ & $506 \mathrm{~m}$ \\
$522 \mathrm{sh}$ & - & - & - & - \\
$547 \mathrm{sh}$ & - & - & - & - \\
$577 \mathrm{vw}$ & - & $566 \mathrm{~s}$ & - & $558 \mathrm{vs}$ \\
$608 \mathrm{~s}$ & $615 \mathrm{~s}$ & - & $605 \mathrm{~s}$ & - \\
$839 \mathrm{w}$ & $842 \mathrm{w}$ & $832 \mathrm{~m}$ & $838 \mathrm{w}$ & $827 \mathrm{w}$ \\
$886 \mathrm{vs}$ & $892 \mathrm{vs}$ & $879 \mathrm{vs}$ & $885 \mathrm{vs}$ & $872 \mathrm{vs}$ \\
$915 \mathrm{sh}$ & - & $920 \mathrm{w}$ & - & $914 \mathrm{w}$ \\
$955 \mathrm{w}$ & $964 \mathrm{w}$ & $945 \mathrm{sh}$ & $954 \mathrm{w}$ & $945 \mathrm{~s}$ \\
$982 \mathrm{vs}$ & $990 \mathrm{~s}$ & $963 \mathrm{sh}$ & $982 \mathrm{vs}$ & - \\
$1000 \mathrm{sh}$ & $1001 \mathrm{sh}$ & - & - & - \\
\hline \hline
\end{tabular}

The comparison of the literature X-ray powder diagrams of forsterite and fayalite, on the one hand, and of the studied sample, on the other hand (Figure 17), as well as the registered complete agreement of the XRPD data of the studied olivine specimen from Ržanovo with the corresponding diagram of forsterite (see Table 34 in ref. 16) undoubtedly proves that the chemical composition of the studied sample is much closer to forsterite end-member. The results obtained by IR and Raman spectroscopy as well as by XRPD were confirmed by the X-ray microprobe analysis (Table 6). 


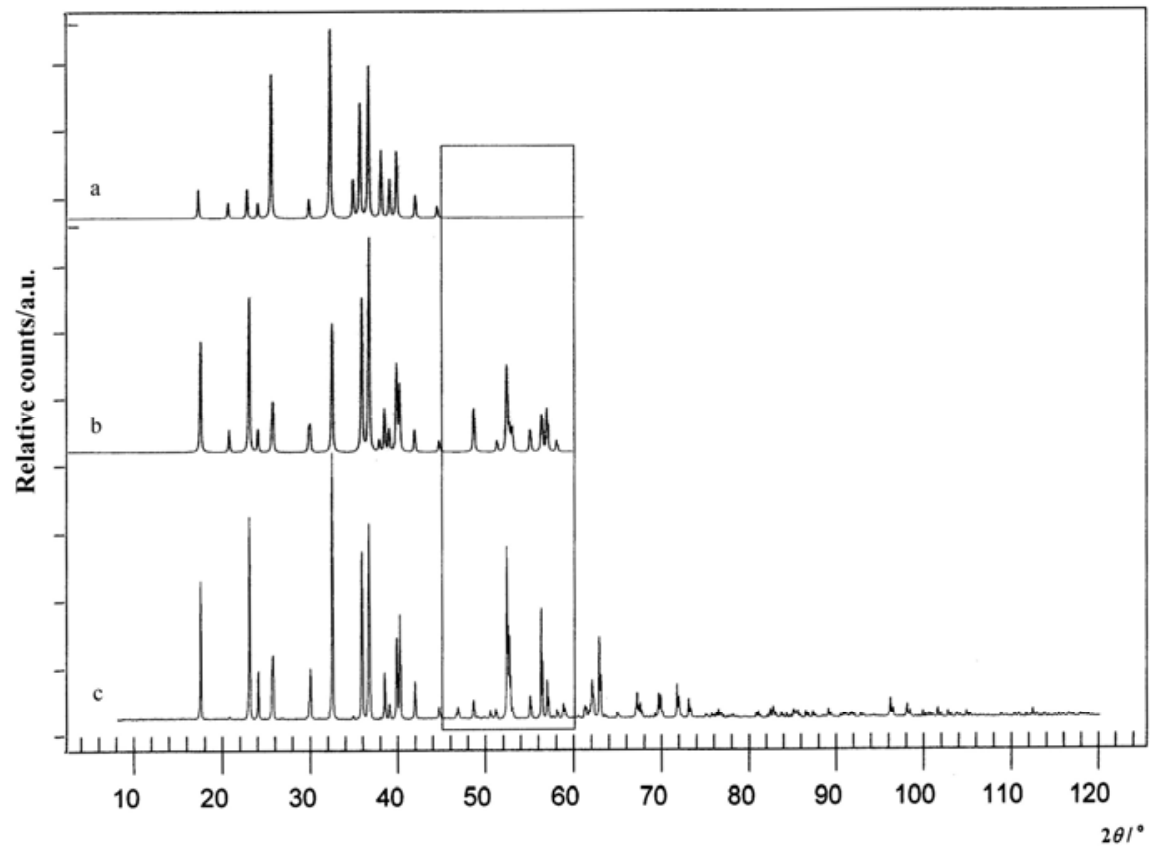

Fig. 17. X-ray powder pattern of fayalite (a), forsterite (b) and the studied olivine sample from Ržanovo (c)

T a b le 6

The chemical composition and the unit cell parameters $(\dot{A})$ of the studied olivine sample from Ržanovo compared to the corresponding data for the samples with the chemical composition close to forsterite and fayalite end members

\begin{tabular}{lcccccc}
\hline \hline & $\begin{array}{c}\text { Ideal } \\
\text { Chemistry }\end{array}$ & Obtained Chemistry & $a$ & $b$ & $c$ & $V / \AA^{3}$ \\
\hline This work & & $\left(\mathrm{Mg}_{1.68}, \mathrm{Fe}^{2+}{ }_{0.32}\right) \mathrm{SiO}_{4}$ & 4.7633 & 10.2280 & 5.9909 & 291.87 \\
Forsterite & $\mathrm{Mg}_{2} \mathrm{SiO}_{4}$ & $\left(\mathrm{Mg}_{1.82}, \mathrm{Fe}_{0.18}\right) \mathrm{SiO}_{4}$ & 4.7617 & 10.2255 & 5.9927 & 291.79 \\
Fayalite & $\mathrm{Fe}^{2+}{ }_{2} \mathrm{SiO}_{4}$ & $\left(\mathrm{Fe}^{2+}{ }_{1.88}, \mathrm{Mn}_{0.12}\right) \mathrm{SiO}_{4}$ & 4.8177 & 10.477 & 6.0922 & 307.5 \\
\hline \hline
\end{tabular}

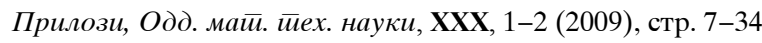




\subsection{Advantages of vibrational spectroscopy over XRPD}

Beryl, $(\mathrm{Be}, \mathrm{Mg}, \mathrm{Fe})_{3} \mathrm{Al}_{2} \mathrm{Si}_{6} \mathrm{O}_{18}$

Although beryl is a nominally anhydrous mineral, the room temperature (RT) IR spectra in the region of $\mathrm{H}_{2} \mathrm{O}$ (and $\mathrm{OH}$ ) stretching vibrations of the studied beryl sample from Čanište (Fig. 18 - left, second spectrum) demonstrates the existence of two well-resolved bands centered at $3592 \mathrm{~cm}^{-1}$ (B-notation) and $3660 \mathrm{~cm}^{-1}$ (C-notation) whereas in the corresponding liquid nitrogen temperature (LNT) IR spectrum (Fig. 18 - left, first spectrum) additional very weak band at $3697 \mathrm{~cm}^{-1}$ (A-notation) is defined [24]. Such a spectral view is a strong indication about the dominant presence of one type of $\mathrm{H}_{2} \mathrm{O}$ molecules in the existing channels along the $c$-axis in beryl structure [25, 26]. Namely, type I $\mathrm{H}_{2} \mathrm{O}$ molecules (arranged so that the symmetry axis of the molecule is perpendicular to the channel axis and typical for alkali-free beryls), represented by the bands in 3690-3699 $\mathrm{cm}^{-1}$ and 3629-3650 $\mathrm{cm}^{-1}$ regions (see Table 4 in ref. 24), are practically absent in our RT spectrum (except the very weak peak at 3697 $\mathrm{cm}^{-1}$ in LNT spectrum). On the other hand, the bands from the stretchings of the type $\mathrm{II} \mathrm{H}_{2} \mathrm{O}$ molecules (connected with alkali-bearing beryls) appear in $3660-3674 \mathrm{~cm}^{-1}$ and $3590-3596 \mathrm{~cm}^{-1}$ regions being typical characteristic for the studied beryl specimen. Furthermore, the $\mathrm{H}_{2} \mathrm{O}$ bending vibration $\left(1623 \mathrm{~cm}^{-}\right.$

${ }^{1}$, Fig. 18 - right) could serve as an additional evidence for the presence of type II $\mathrm{H}_{2} \mathrm{O}$ molecules since its wavenumber is about $20 \mathrm{~cm}^{-1}$ higher than the corresponding band of type $\mathrm{I}_{2} \mathrm{O}$ molecules (absent in the studied IR spectrum). The studied beryl neither contains third $\mathrm{H}_{2} \mathrm{O}$ type that has the same direction of $\mathrm{C} 2$ symmetry axis as type I water [25] nor $\mathrm{CO}_{2}$ molecules because the bands due to their IR active modes are not registered (see Table 4 in ref. 24).

The Raman spectrum of beryl in $\mathrm{H}_{2} \mathrm{O}$ stretching region (Fig. 19 - left) conforms to the expectations derived from the IR counterpart [24]. Namely, the strong band at $3596 \mathrm{~cm}^{-1}$ undoubtedly arises from the $v_{1}$ mode of the type II water molecules whereas the band showing very weak intensity at $3663 \mathrm{~cm}^{-1}$ could be attributed to the corresponding $v_{3}$ type vibration. The band from the $\mathrm{H}_{2} \mathrm{O}$ deformations is weak and appears at $1610 \mathrm{~cm}^{-1}$ (Fig. 19 - right). No bands from type I water molecules are registered in the stretching and bending regions being additional, indirect, confirmation for their absence in the crystal structure of the studied beryl specimen. 


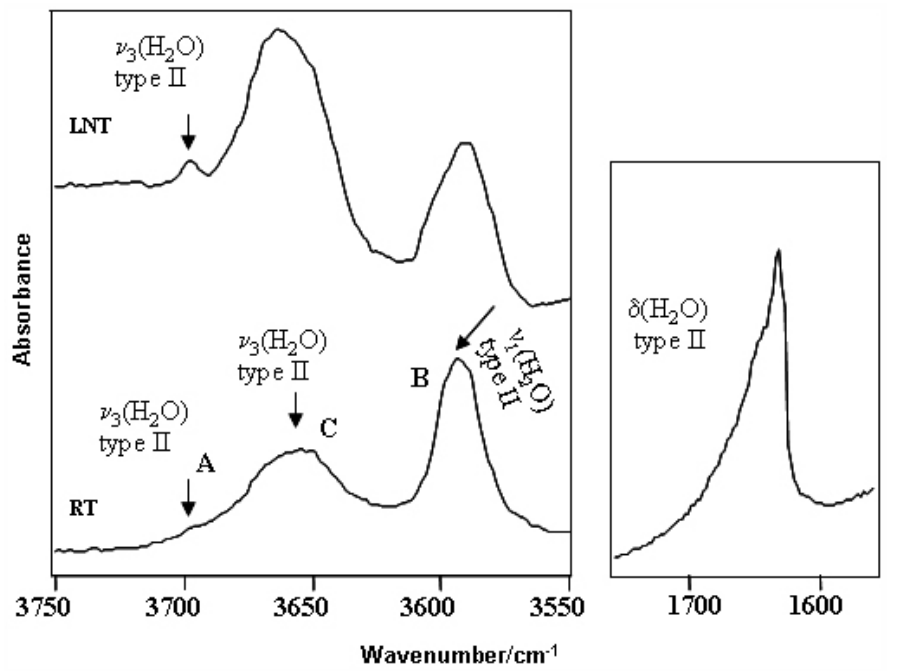

Fig. 18. FT IR spectrum of beryl from Čanište in stretching $\mathrm{H}_{2} \mathrm{O}$ region (left) and bending $\mathrm{H}_{2} \mathrm{O}$ region (right) (RT - room temperature spectrum; LNT - liquid-nitrogen temperature spectrum)

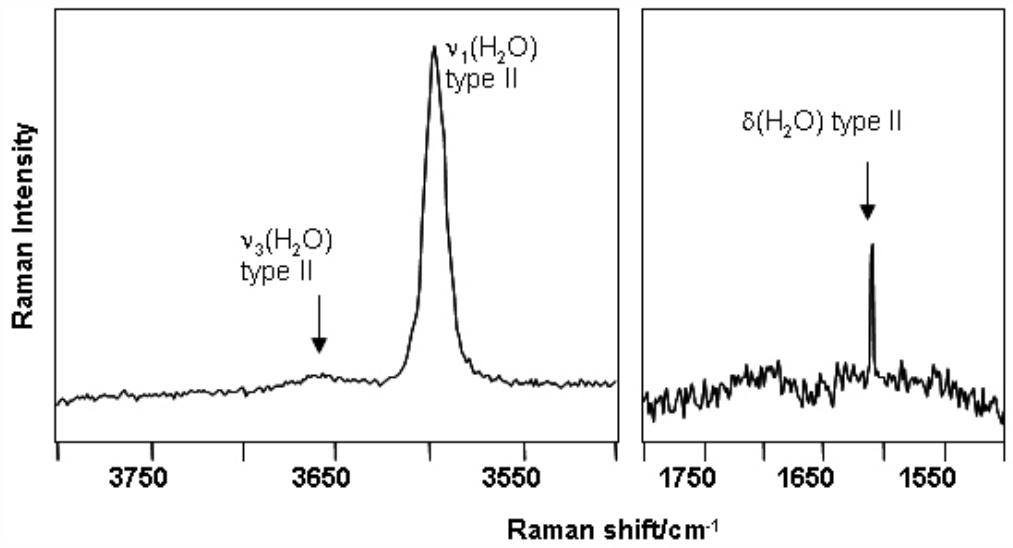

Fig. 19. Raman spectrum of beryl from Čanište in stretching $\mathrm{H}_{2} \mathrm{O}$ region (left) and bending $\mathrm{H}_{2} \mathrm{O}$ region (right)

Here it should be pointed out that X-ray powder diffraction is helpless technique for detection the presence of water molecules in the studied beryl sample. 


\subsection{Advantages of Raman vibrational spectroscopy over FT IR}

Phlogopite, $\mathrm{KMg}_{3}\left(\mathrm{Si}_{3} \mathrm{Al}\right) \mathrm{O}_{10}(\mathrm{~F}, \mathrm{OH})_{2}$;

Clinochlore (sheridanite), $(\mathrm{Mg}, \mathrm{Al})_{6}(\mathrm{Si}, \mathrm{Al})_{4} \mathrm{O}_{10}(\mathrm{OH})_{8}$

The infrared spectrum of phlogopite sample from Sivec in the 4000$400 \mathrm{~cm}^{-1}$ region is presented in Fig. 20a and band assignment is given in Table 4 of ref. 27. The medium band registered at $1456 \mathrm{~cm}^{-1}$ as well as the weak bands at 882 and $727 \mathrm{~cm}^{-1}$ (the latter one overlapped by the fundamental band at $730 \mathrm{~cm}^{-1}$ ) (Fig. 20a) are neither expected nor observed in the corresponding literature data [27]. It is explained by the presence of carbonate impurities in the sample supported by the fact that the band wavenumber strongly coincide with the corresponding one in the dolomite IR spectrum shown in Fig. 20e. After treatment of the phlogopite sample by $3 \mathrm{M} \mathrm{HCl}$, the carbonate phase was totally removed (Fig. 20b). The overlapping is additionally confirmed by sample treating with diluted $\mathrm{HCl}$ solution (Fig. 20b). Namely, despite the complete elimination of the bands originating from the carbonate phase (Fig. 20a vs. Fig. 20b), the absorbance near $730 \mathrm{~cm}^{-1}$ remained (Fig. 20b).

The presence of the carbonate impurities was also registered in the FT IR spectrum of the clinochlore (sheridanite) being manifested by appearance of the additional bands at 1449, 881 and $728 \mathrm{~cm}^{-1}$ (Fig. 20c). After treatment of the sample in $3 \mathrm{M} \mathrm{HCL}$, the carbonate phase was totally eliminated (Fig. 20d).

The Raman spectrum of phlogopite sample was recorded using the 514, 532 and $1064 \mathrm{~nm}$ excitation lines (Fig. 21, a, b and c). The peaks in the studied region $\left(1200-100 \mathrm{~cm}^{-1}\right)$ are found at almost identical frequencies in all three spectra (see also Table 5 in ref. 27). The highest-wavenumber doublet (around 1100 and $\left.1085 \mathrm{~cm}^{-1}\right)$ appears from the strongest $v_{1}\left(\mathrm{CO}_{3}{ }^{2-}\right)$ mode of the carbonate impurities: calcite $\left(1095 \mathrm{~cm}^{-1}\right)$ and dolomite $\left(1086 \mathrm{~cm}^{-1}\right)$ (Fig. 21, e and f). The peaks around 300,280 and $170 \mathrm{~cm}^{-1}$ also arise from calcite and dolomite impurities (see Fig. 21, e and f).

It is evident that, compared to the broader IR bands, the narrow Raman bands makes possible to clearly discriminate between the calcite and dolomite carbonate impurities in the studied phlogopite sample. In this context, Raman spectroscopy enables to differentiate between the isomorphous minerals.

Similar spectral behaviour concerning the presence of the discriminative calcite and dolomite impurity bands is observed in the case of the Raman spectrum of clinochlore (sheridanite) (Fig. 21d). 


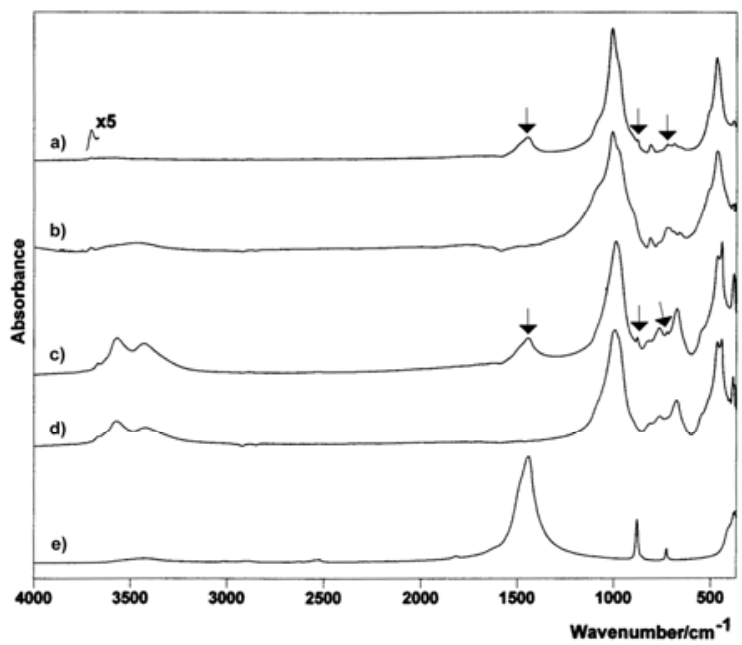

Fig. 20. FT IR spectra of phlogopite from Sivec (a) and clinochlore (sheridanite) from Sivec (c) obtained using KBr pellets. The IR spectra of the samples after elimination of carbonate impurities (treatment by diluted $\mathrm{HCl}$ ) are given under (b) and (d), respectively. IR bands that appear from dolomite (e) impurity are marked by arrows.

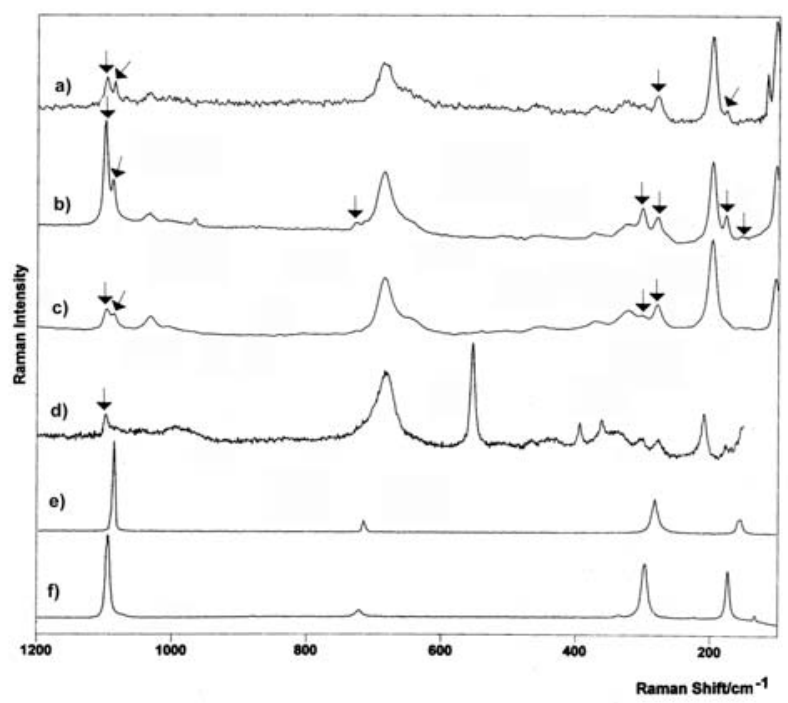

Fig. 21. Raman spectra of phlogopite from Sivec (a, b, c) obtained using 514, 532 and $1064 \mathrm{~nm}$ excitation line, respectively, and clinochlore (sheridanite) from Sivec using $514 \mathrm{~nm}$ line (d). The Raman bands that appear from the calcite (e) and dolomite (f) impurities are marked by arrows.

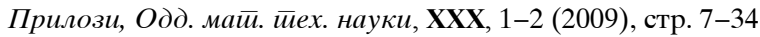




\section{REFERENCES}

[1] D. Bish, J. Post, Quantitative Mineralogical Analysis Using the Rietveld Full-pattern Fitting Method, Am. Mineral., 78 (1993) 932-940.

[2] E. Libowitzky, Crystal Structure Dynamics: Evidence by Diffraction and Spectroscopy, Croat. Chem. Acta, 79 (2006) 299-309.

[3] D. Yu. Pushcharovsky, Recent Contributions and Modern Perspectives in XRD Studies of Minerals, Croat. Chem. Acta, 73 (2000) 869-886.

[4] V. C. Farmer (Ed.), The Infrared Spectra of Minerals, Mineralogical Society, London, 1974.

[5] P. F. McMillan, A. M. Hofmeister, Infrared and Raman Spectroscopy, - In F. C. Hawthorne (Ed.): Spectroscopic Methods in Mineralogy and Geology, Rev. Mineral., 18 (1988) 99-157.

[6] W. P. Griffith, Raman Spectroscopy of Minerals, in: V. C. Farmer (Ed.), The Infrared Spectra of Minerals, Mineralogical Society, London, 1974, pp. 119-135.

[7] L. Burgio, R. J. H. Clark, Library of FT-Raman Spectra of Pigments, Minerals, Pigment Media and Varnishes, and Supplement to Existing Library of Raman Spectra of Pigments with Visible Excitation, Spectrochim. Acta, 57A (2001) 1491-1521.

[8] R. Shirley, The CRYSFIRE System for Automatic Powder Indexing. (http://www.ccp14.ac.uk/tutorial/crys/)

[9] LMGP-Suite Suite of Programs for the interpretation of X-ray Experiments, by Jean Laugier and Bernard Bochu, ENSP/Laboratoire des Matériaux et du Génie Physique, BP 46. 38042 Saint Martin d'Hères, France. (http://www.inpg.fr/LMGP and http://www.ccp14.ac.uk/tutorial/lmgp/)

[10] GRAMS32 for Microsoft Windows, Vers. 4.10, Galactic Industries Corporation, 1991-1996.

[11] P. Makreski, G. Jovanovski, B. Kaitner, T. Stafilov, B. Boev, D. Cibrev, Minerals from Macedonia. X. Separation and Identification of Some Oxide Minerals by FT IR Spectroscopy, AAS, AES-ICP and Powder XRD, Neues Jahrb. Mineral. Abh., 180 (2004) 215-243.

[12] L. G. Berry, R. M. Thompson, X-ray Powder Data for Ore Minerals: The Peacock Atlas, Geological Society of America, New York, 1962.

[13] V. C. Farmer (Ed.), The Infrared Spectra of Minerals, Mineralogical Society, London, 1974.

[14] H. D. Lutz, H. Haeuseler, Infrared and Raman Spectra of Inorganic Solids - State of the Art, Trends Appl. Spectrosc., 2 (1998) 59-88.

[15] C. J. Serna, J. L. Rendon, J. E. Iglesias, Infrared Surface Modes in Corundum-Type Microcrystalline Oxides, Spectrochim. Acta, 38A (1982) 797-802. 
[16] G. Jovanovski, P. Makreski, B. Šoptrajanov, B. Kaitner, B. Boev, Minerals from Macedonia. Complementary Use of Vibrational Spectroscopy and Powder X-ray Diffraction for Identification and Detection Purposes, Contributions, Sec. Math. Tech. Sci., MANU, 26 (2005) 7-84.

[17] Powder Diffraction File-4/Minerals, International Center for Diffraction Data, Pennsylvania, 2005.

[18] P. Makreski, G. Jovanovski, S. Stojančeska, Minerals from Macedonia. XIII: Vibrational Spectra of Some Commonly Appearing Nesosilicate Minerals, J. Mol. Struct., 744-747 (2005) 79-92.

[19] P. Makreski, G. Jovanovski, Minerals fro Macedonia. XXII. Laser-induced Fluorescence Bands in the FT-Raman Spectrum of Almandine Mineral, J. Raman Spectrosc., 39 (2008) 1210-1213.

[20] P. Makreski, G. Jovanovski, A. Gajović, T. Biljan, D. Angelovski, R. Jaćimović, Minerals from Macedonia. XVI. Vibrational Spectra of Some Common Appearing Pyroxenes and Pyroxenoids, J. Mol. Struct., 788 (2006) 102-114.

[21] G. Jovanovski, P. Makreski, B. Kaitner, B. Boev, Silicate Minerals from Macedonia. Complementary Use of Powder X-ray Diffraction and Vibrational Spectroscopy for Identification and Detection Purposes, Croat. Chem. Acta, 82 (2009) 363386.

[22] P. Tarte, Etude infra-rouge des orthosilicates et des orthogermanates - II: Structures du type olivine et monticellite, Spectrochim. Acta, 19 (1963) 25-47.

[23] R. G. Burns, F. E. Huggins, Cation Determinative Curves for Mg-Fe-Mn Olivines from Vibrational Spectra, Am. Mineral., 57 (1972) 967-985.

[24] P. Makreski, G. Jovanovski, Minerals from Macedonia. XXIII. Spectroscopic and Structural Characterization of Schorl and Beryl Cyclosilicates, Spectrochim. Acta, 73A (2009) 460-467.

[25] R. I. Mashkovtsev, A. S. Lebedev, Infrared Spectroscopy of Water in Beryl, Zh. Strukt. Khim., 33 (1992) 930-933.

[26] B. Charoy, P. De Donato, O. Barres, C. Pinto-Coelho, Channel Occupancy in an Alkali-poor Beryl from Serra Branca (Goias, Brazil): Spectroscopic Characterization, Am. Mineral., 81 (1996) 395-403.

[27] V. Šontevska, G. Jovanovski, P. Makreski, A. Raškovska, B. Šoptrajanov, Minerals from Macedonia. XXI. Vibrational Spectroscopy as Identificational Tool for Some Phyllosilicate Minerals, Acta Chim. Slov., 55 (2008) 757-766. 
Р е $з$ и м е

\section{МИНЕРАЛИ ОД МАКЕДОНИЈА. \\ РЕНДГЕНСКА ДИФРАКЦИЈА НА СПРАШЕНИ ОБРАСЦИ НАСПРОТИ ВИБРАЦИОНА СПЕКТРОСКОПИЈА ПРИ ИДЕНТИФИКАЦИЈА НА МИНЕРАЛИ}

Споредбено се прикажани некои од предностите и недостатоците во случаите кога рендгенската дифракција на спрашени обрасци, фурие-трансформната инфрацрвена или раманската вибрациона спектроскопија се користат како одвоени техники во процесот на детекција, идентификација, разликување и карактеризација на минералите. Изучуваните минерални примероци: рутил, $\mathrm{TiO}_{2}$; хематит, $\mathrm{Fe}_{2} \mathrm{O}_{3}$; алмандин, $\mathrm{Fe}_{3} \mathrm{Al}_{2}\left(\mathrm{SiO}_{4}\right)_{3} ;$ спесартин, $\mathrm{Mn}_{3} \mathrm{Al}_{2}\left(\mathrm{SiO}_{4}\right)_{3}$; лимонит, $\mathrm{FeO}(\mathrm{OH})$; гетит, $\alpha-\mathrm{FeO}(\mathrm{OH})$; феројохансенит, $\mathrm{Ca}(\mathrm{Fe}, \mathrm{Mn}) \mathrm{Si}_{2} \mathrm{O}_{6}$; оливин, $(\mathrm{Mg}, \mathrm{Fe})_{2} \mathrm{SiO}_{4}$; форстерит, $\mathrm{Mg}_{2} \mathrm{SiO}_{4}$; фајалит, $\mathrm{Fe}_{2} \mathrm{SiO}_{4}$; берил, $\mathrm{Be}_{3} \mathrm{Al}_{2} \mathrm{Si}_{6} \mathrm{O}_{18}$; флогопит, $\mathrm{KMg}_{3}\left(\mathrm{Si}_{3} \mathrm{Al}\right) \mathrm{O}_{10}(\mathrm{~F}, \mathrm{OH})_{2}$ и клинохлор (шериданит), $(\mathrm{MgFe})_{5} \mathrm{Al}\left(\mathrm{Si}_{3} \mathrm{Al}\right) \mathrm{O}_{10}(\mathrm{OH})_{8}$ се собрани од разни локалитети на Република Македонија.

Клучни зборови: минерали; рендгенска дифракција на спрашени обрасци; вибрациона (инфрацрвена и раманска) спектроскопија

Address:

\section{Gligor Jovanovski}

Macedonian Academy of Sciences and Arts,

P.O. Box 428, MK-1001 Skopje, Republic of Macedonia

E-mail: gligorj@manu.edu.mk

Institute of Chemistry, Faculty of Science, Ss. Cyril and Methodius University in Skopje, P.O. Box 162, MK-1001 Skopje, Republic of Macedonia

E-mail: gligor@pmf.ukim.mk

\section{Petre Makreski}

Institute of Chemistry, Faculty of Science, Ss. Cyril and Methodius University in Skopje,

P.O. Box 162, MK-1001 Skopje, Republic of Macedonia

E-mail: petremak@pmf.ukim.mk

\section{Branko Kaitner}

Department of Chemistry, laboratory of General and Inorganic Chemistry, Faculty of Science, University of Zagreb, Horvatovac 102a, 10000 Zagreb, Croatia

E-mail: kaitner@chem.pmf.hr

\section{Bojan Šoptrajanov}

Macedonian Academy of Sciences and Arts,

P.O. Box 428, MK-1001 Skopje, Republic of Macedonia

E-mail: bojan@manu.edu.mk

Received: 28. X 2009

Accepted: 1. XII 2009 